\title{
IMPORTANCE OF FEMALE ENTREPRENEURSHIP
}

\author{
Kata Keveházi
}

Abstract: Behind the most significant problems of the world - poverty and starvation, wars, environmental pollution and climatic change - there are goals characteristic of the patriarchal society, $i$. e. the extension of power, the acquisition of resources and even the use of violence. One of the main tools of acquiring economic and political advantages is to maintain the subjection of women. Due to their biology, they are exposed to harassment and violence in times of peace and war alike. Their core necessity is their own security and the safety of their children in order to achieve that they endeavour to develop a form of behaviour, an appearance, a life path, a way of life supported by the patriarchate - especially if they have no pecuniary room for manoeuvre. The investment of women with economic power and entrepreneurship activity strengthen their autonomy and influence the its personal, economic and even political sense, and, at the same time, the prevailing of values that go beyond the patriarchal set of verb missing, e.g. are important issues such as: the welfare of children, the elderly, the sick and other persons exposed, preserving environment and safety. The objective of the paper is to raise awareness to the importance of female entrepreneurship, the impediments lying ahead of their progress and set forth the conditions of their development.

Keywords: female entrepreneurship, women entrepreneurs, economic independence, women in political decision making

\section{Background}

\section{Personal motivations}

For sixteen years now, I have been dealing with providing support for women restarting their career, creating equal opportunities for women on the labour market and promoting their economic independence. My endeavour is to assist spreading the application of a gender-based approach as an advisor at individual levels, at an organisational level while elaborating workplace programmes that support women and as a gender expert by making proposals of specialised policy at global societal level. It is my conviction that solving the most significant problems of the world - poverty and starvation caused by the distribution of resources and earnings, wars, pollution of the environment (Braidotti, Charkiewicz, Hausler, Wieringa, 1994), the change of climate, etc. - is inconceivable without questioning and changing the patriarchal order of society and the hierarchy of genders.

The key element of social, economic and environmental sustainability is to promote gender equality. As stated by Kofi Annan, Former United Nations SecretaryGeneral in 2006. "The world is starting to grasp that there is no policy more effective [in promoting development, health and education] than the empowerment of women and 
girls. And I would state that no policy is more important in preventing conflict, or in achieving reconciliation after a conflict has ended" (Fitzpatrick, 2016).

\section{Questioning the global patriarchate}

Patriarchal society, based on continuous power expansion, growth on acquiring the resources even by means of violence and wars, essentially jeopardizes women's pecuniary and physical safety (Haq, 1999). The millenary distribution of tasks between genders, thus, the subordinated social role of women is an essential interest of global patriarchate, as its absence would jeopardize the operability of present societies (Waring, 1989).

The less democratic a state is, the more economic or political power is concentrated in the hands of a restricted circle, the more leaders strive to maintain their power by means of intimidation, violence, political or religious ideologies supporting this, the more typical the effacement of women is, maintaining the subordination of women is increasingly its interest (Hudson et. al. 2009). Throughout the world, economic and social life continues to be organised along the goal of power expansion, and it is not the interest of those who own power to share it to waive the position they occupy in society. Belonging to the masculine gender in itself is already a privilege, girl children andwomen are less appreciated by the societies. Even a man with the lowest status senses the emancipation endeavour of a woman with a status identical to him as a loss of power to a certain degree, therefore it is not surprising that it is equally a primary endeavour of patriarchal structures built on male power to preserve the status quo relevant to gender hierarchy, restrict the actual interference of women and disregard their aspects.

The current determinant political and economic world order, i.e. global capitalism, has been organised along the millenary patriarchal relations system and the subordinated role of women. The past 150 years proved insufficient to have the feminist endeavours aimed at promoting gender equality and eliminate the most ancient inequality in the world that pervades every field of life.

Maximising profit is the central goal of global capitalism. To achieve this end, it exploits the environmental and human resources to the extent allowed by the set of values, rules, the jurisdiction of the societies, or the social groups more remote from power. Since, in the event of holding on to political power, maintaining it is subject to their own economic resources or those of persons belonging to their spheres of interest, the actual role undertaken by a considerable part of the states in the preservation of resources is very meagre - the less democratic a government is, the less extent the aspects of sustainability, social justice, equal chances and freedom of speech prevail. Operability of the world order striving to maintain the power structure continues to be based on the millenary gender distribution of tasks, whose preservation continues to be monitored vigilantly by the male-governed structures. Due to the growth demand of key actors of global capitalism, multinational corporations and states, the economic role undertaken by women has been revalorized both in the developed and developing world, there is increasing talk of women's ability to generate earnings and of their consumption, of the positive impact their economic activity exercises on growth, evidenced by researches, as well (PWC, 2012).

Today's societies need women as a human resource. Regardless of the cultural circle, to an extent and in form that varies by countries, they are present in the world of paid labour, too, they work as employees, entrepreneurs, occasional workers or helping 
family members in the legal, informal or black economy, and, at the same time, they continue to perform the tasks that secure the work-performance of men as well as the life quality of the more elderly and new generations.

Taking care of the children, the elderly, the sick, the reproduction of men's earning and power-exercising capacity by itself restricts their participation and their exposure to discrimination in the world of labour and also maintains their secondary labour status since coping with domestic tasks restricts their opportunities of taking up a job and promotion in terms of time and space too. Two-thirds of unpaid and paid jobs are performed by women. At the same time, patriarchal society does not appreciate the caregiver activities so women are left with hardly $10 \%$ of the world's earnings and hardly 1\% of the assets (GENDERNET, 2012). In case they perform a paid job, a disproportionate number of them works in the sectors of caregiving, education, health, hence, their earnings and pension show a durable, life-long lagging behind those of the men even in the developed world. Besides, gender affiliation multiplies other disadvantages - that stems from belonging to a disability, ethnic or another underprivileged group - from the aspect of e.g. lodging, access to the core infrastructure or health services, exposure to violence and discrimination (Castiello et. al. 2013). One of the main indicators of dedication of a state or a society to change the hierarchic set of gender relations therefore is not whether the participation of women in the labour market is allowed or incentivised, but rather where they strive to take over women's reproduction and caregiving activities as a state task, supervise the distribution of tasks in private life and improve the role of women in decision-making.

Today patriarchal societies face the serious challenge of deciding on the proportion to have recourse to, or utilize simultaneously the economic and caregiving potential inherent in women; the point where to designate the boundaries between paid and unpaid activities performed by women, the type of social system for reproducing human resources they should operate as the participation of women in paid labour inevitably raises the questioning of women's subordinated role.

In the globalising economy, societies disposing of a different culture in terms of gender equality, strive on the one hand, to meet more or less the minimum of human rights recorded in the basic documents of international organisations. However, on the other hand, they deem it their inalienable right to determine where the place of women is, restrict or incite maternity, take up jobs, facilitate or aggravate studies, divorce, entertainment and the autonomy and rights of women. This contradiction is conspicuous especially in the European Union where transplanting values relevant to the equality of women and men into comprehensive gender equality policies and programmes of national scale have failed.

Merging women's situation with the families' situation - which, for instance in Hungary, is very deep-rooted in public thinking - successfully diverts attention from the balance of power within the family to the utilisation of earnings, the domestic distribution of tasks and access to leisure (Acsády et. al., 2012). We should recognize that women are one of the most important tools and victims of sustaining patriarchal society (Ferguson et. al. 2016), to a larger extent compared to men at the identical levels of social hierarchies.

\section{Women in the patriarchate}

Women are naturally present at the highest level of social and economic hierarchies. The importance of female leaders has undoubtedly also increased within the 
patriarchal organisational hierarchies striving to maximise influence and profit as they build upon women's purchasing power, too, on their consumer markets. At the same time, they represent a trifling proportion at the top executive levels, thus, although women represent and would stand for a lot more the aspects of equal chances, welfare and environment, the values of tolerance and understanding, the executive style based on involvement and democratic participation (Eagly and Carli, 2007). Their influence, in general, consists in supporting initiatives of such orientation with regard to participation in the global problems so they are present rather in the role of wives than executives of high-powered global companies. The scant participation of women in management is negligible at multinational organisations, higher-powered in case of the states, not merely upon their business goals, investments and social programs but also their organisational culture. Even in the IT sector showing the highest commitment to women's participation, the typical labour-market disadvantages of women (pay gap, glass ceiling, etc.) are reproduced, attached to their involvement, and the harassment and disparagement of women is just as typical as in any other patriarchal medium (Frost, 2017). At the same time, women who acquire executive roles in the patriarchal structures, conclude their own patriarchal bargain (Kandiyoti, 1988) in order to develop and safeguard their position, measuring and validating themselves and their fellow women using the set of values of men, and the male-governed structures and patriarchate.

Women's appreciation, moreover, in certain societies, the basis of their existence straightforward is their biological suitability (their ability to bear children, their beauty), or the performance of caregiving activities deduced from the biological role, provided for free. In order to maintain the subordinated position and fulfil the expectations stemming from the gender role, they are exposed to harassment and violence in peace and war times alike (Manjoo and McRaith, 2010).

The collective and transmitted trauma of physical, sexual, economic, spiritual and verbal violence to which women are exposed, well-known to generations, compels women to adapt themselves instinctively, partially or completely consciously to the patriarchal set of rules, to apply specific fighting techniques - in many cases in return simply for their own and their children's physical and material safety (Tickner, 2004). Violence against women affects every third woman (European Union Agency for Fundamental Rights, 2014), in the private sphere, spiritual, physical, sexual, economic and physical violence is general, at the same time, its institutionalized forms - mutilation of the female genital organ, coerced marriage, coerced sterilization and the selective abortion of female foetuses, prostitution and trafficking in human beings are the major jeopardy to hundreds of millions of women (UN Report World's Women, 2015), to the safety of women, as well as the mass violence deployed during wars as a weapon.

Thus, security is the basic need of women, and with a view to achieve it, they generally endeavour to develop a behaviour, look, life path, way of life, family model supported by the patriarchate - especially if they have no pecuniary room of their own for manoeuvre, for choices corresponding to their own ideas, needs, desires.

\section{The importance of women's economic independence}

One of the principal traps set by patriarchal society for women is the message whereby men create the safety of women, whilst it is precisely the subsistence of the patriarchal set of values based on women's subordination that constitutes the main source of jeopardy for women's long-term individual safety and for the safety of women 
and children. A core condition to women's safety is to cease their dependence and helplessness whose key factor is to invest women with power at an individual level, to support the creation of their autonomy and economic independence, and at the social level, to promote their equal access to political, social power and to the power enabling the forming of opinion. Via female enterprises, under operational conditions created by women, supported by digital technology, the disadvantages of women in terms of resources affecting monetary- and social capital can be offset in particular, they can become capable of a business performance even surpassing men, being able to represent the values important for them as well (Kevehazi, 2016).

I would subsequently like to talk about the female entrepreneurial activity which provides women with earnings obtained in their own right, at the same time, confirms their ability to independently prosper, reduces their insecurity with regard to the ability of taking care of their children, hence encourages other women as well to strive to assume their autonomy in personal, economic, even political sense, to make independent decisions, to stand up for themselves and their environment.

Female entrepreneurial activity - I am convinced - , women's genuine pecuniary and spiritual independence, a higher proportion of women becoming entrepreneurs, the strengthening of their enterprises are the factors that can strengthen women's proportionate participation in the decision-making of societies. The economic power of female entrepreneurs, the deploying of their self-assertion skills, their assuming responsibility for themselves and their own sort will allow for an ever-increasing number of women to recognize their own skills, opportunities, acquire economic independence and represent the society values that go beyond the patriarchal set of values: the welfare of children and other helpless persons, caregiving, preserving the environment and safety. The key element of social, economic and environmental sustainability is to extend women's personal autonomy and their rights to strengthen their enterprises.

My paper is based on the processing of international specialized literature and the research niche I conducted between 2015 and 2016 in Hungary while working at civil organisations during which I examined the features characteristic and specific of female enterprises along with the social, economic, structural impediments and approaches that stand in the way of women becoming entrepreneurs and women gaining strength as entrepreneurs. Women resident at 187 various settlements participated in the survey conducted by way of questionnaires, nearly 80 women participated in 10 towns in focus group discussions, moreover, we interviewed numerous experts experienced in the development of enterprises. My aim is to cast light on the aspects, reasons and nature of gender inequalities characteristic of enterprising. Namely, without revealing and following up the inequalities, without commitment to their termination in principle and also manifesting it in actions without carrying out interventions at system-level, it is impossible to create social justice between women and men.

\section{Inequalities between genders in the business sector}

Should they live in any region of the world, due to the genders' different roles and opportunities for getting on, to date, female entrepreneurs face numerous social and cultural impediments that determine their career prior to the entrepreneurial activity, influence the circumstances of launching their enterprise, and subsequently also hinder the development of their enterprise and aggravate its survival. Visible and invisible impediments are associated with the patriarchal set of values and the patriarchal 
mechanisms maintaining inequalities whose determinant tools are stereotypes attached to gender roles that, again and again, reproduce the barriers of approach.

\section{Gender-based stereotypes determining the entrepreneurial activity of women}

The business sector is essentially dominated by men to date, the role model of entrepreneurs is conceived as male by the majority of society to this day. Namely, education that stresses and supports the different qualities, skills of boys and girls, and training that prepares for the traditional gender roles, do not strengthen the qualities necessary to launch an enterprise - willingness to assume risk, independence, selfconfidence - in the case of girls, or less than in the case of boys. According to socialization and the stereotypical views confirmed by the media women are - as they say - "emotional beings", it is almost like advancing that enterprising is not a field for women since women:

- are not tough enough for business,

- are incapable of making rational decisions,

- are impressionable, therefore unsuitable for an executive role to manage people.

- companions, private life are more important to them, thus, they are not sufficiently reliable, etc.

Women interiorize the gender-based stereotypes, they determine their choice of career, career ideas, expectations of earnings, requirements for financial independence at a lower level compared with men subordinated to family life. Their self-assessment is largely influenced by the social expectations attached to female roles, physical look, the existence of companions, the fact of childbirth, the clever running of household, compliance with the scope of caregiver task (Pérez et. al. 2015).

\section{Female life strategies in the entrepreneurial activity}

The extension of female roles, occurred in the last century, did not bring along the transformation of male roles: the distribution of domestic roles is still determined by the model of a male breadwinner. The necessity or need to earn money is still a secondary social expectation in the case of women regardless of women assuming an everincreasing part of the family costs of living, moreover, in an ever-increasing proportion of the households, the woman is the primary, or the only breadwinner.

However, due to the female life cycle and roles different from the male ones, compliance with the family obligations is especially emphatic for women at certain life stages, which, as long as they live, affects their participation in the world of paid work, the development of earnings acquired in their own right, the freedom of their decisions and their safety.

According to the female life-strategies offered to them, female entrepreneurs living in societies that belong to different cultures form essentially part of three well-separable groups in terms of participating in the world of paid work:

- dependent existence: performing the domestic tasks, lasting absence from the labour market or absence from it all their lives

- combination strategy: restricted presence on the labour market with regard to promotion opportunities, subordinated to the obligations of private life in terms of time and space 
- career strategy: its goal is durable presence on the labour market, exploiting the skills, earnings acquired in one's own right (Bernhardt, 2000).

A considerable part of women, although they do not take up a paid job and do not possess a proprietorship ratio within, contribute to the development of their husband's/partner's enterprise, support it, subordinating their personal development, their own goals, knowledge and livelihood to the breadwinner activity of the head of the family. Their environment but even often they think of themselves as the helper of their husband/partner, eventually even if the also hold formally their own stake of ownership in their husband's firm based on which they could acquire earnings in their own right.

Pecuniary exposure considerably increases the chance of economic and other violence against women in the couples. An eventual breaking up of the couple - despite the rights enforceable during divorce - significantly jeopardizes pecuniary security as the enterprise can be essentially linked to the man's activity. Those thinking in terms of the combination strategy are active on the one hand in a joint venture with their husband/partner, on the other hand, have an enterprise of their own, yet subordinate it to the family, enterprising being a complementary activity for them. These women strive less to or are forced less to remain in the background.

A substantial part of female enterprises is a single-person enterprise, which could mean that growth of the enterprise, the upward-swinging career equally rank among the personal goals. At the same time, for the majority of these female entrepreneurs, an aspect determining daily operation and one of the main barriers to their growth is the endeavour for the compatibility of family and work (Kelley et. al. 2015). Female entrepreneurs setting themselves the career strategy - although private life is by all means no less important for them either, moreover, they even strive to reconcile work and private life - do not restrict the development of their enterprise: if necessary, they do several hours of workplace overtime, hire an employee, eventually they undertake even absence, travel, etc.

\section{The impact of gender roles and stereotypes on the position of female entrepreneurs}

As a result of stereotypes restricting the willingness of women to embark upon enterprises, their urges to launch an enterprise, education and socialization for the prescribed gender roles, furthermore, due to their roles and position in private life, compared with men, female entrepreneurs

- dispose of less external resources (financial, technological and social capital required for the entrepreneurial activity);

- dispose of less internal resources (self-confidence, assertiveness regarding their executive competences, willingness to assume risk, in certain countries, knowledge, expertise, etc.) that could support their entrepreneurial activity;

- can devote less time to their enterprising activity due to their family obligations, the unequal distribution of domestic tasks and the related external and internal expectations

- dispose of lesser mobility opportunities due to their private life obligations, their scantier resources, in certain cultures, do the set of its customs, elsewhere, due to the restricted safety of women; moreover

- from a pecuniary and emotional aspect, they enjoy less family support; 
- they are less accepted, appreciated at social level too, since gender stereotypes directly impact social representations of their role opportunities; they are exposed to disparagement, harassment from the side of their male competitors, business partners, - to exclusion from the male networks, in certain countries, from professions, etc., and this latter in turn impacts all the foregoing factors.

\section{Different motivations of the genders}

All over the world, necessities, constraints or personal urges can be found in the background of women and men launching their enterprise. In countries with a restricted labour market, enterprising activity is typically the only source of livelihood, of survival. A consequence of different expectations applicable to gender roles is that all over the world, women become entrepreneurs rather out of necessity, constraint (this is the socalled push-factor), then because of enterprising as an activity being attractive to them (pull-factor) (Kirkwood, 2009). In countries with a low GDP, a significant proportion of them perform their enterprise activity informally, in their home, sacrificing their sparetime, typically for the sake of mere survival, to satisfy the family's core necessities.

Following the crisis of 2008, the number of coerced enterprises has substantially increased in the developed world too. At the same time, the difference between the motivation of women and men is less, they are frequently compelled to launch an enterprise by changes having occurred in their life situation, like a divorce, the insecurity or lack of a work-place or the husband's/partner's loss of job. Although the proportion of informal enterprises is lower in the developing societies, it is still more typical of female entrepreneurs, as women more frequently embark upon entrepreneurship as an activity completing their principal one - besides running a household, performing the caregiving activities, or eventually in addition to having a job. This is also supported by the fact that whilst in countries with low earnings $74 \%$ of women launch an enterprise; in countries with medium earnings $91 \%$ of them; and in those with high earnings, and $82 \%$ of them start an enterprise in addition to their existing occupation (Minniti, M, 2010).

The difficulties involved in enterprise activity, the unpredictability of earnings, success hold back many from launching their enterprising even if otherwise, the independence, self-determination, free disposal of time offered by the entrepreneurial existence were attractive to them. In the case of women, risks are primarily overwritten by the compatibility of work and family, men are a lot more inclined to assume uncertainty inherent in the entrepreneurial existence as to work for someone else.

\section{Female entrepreneurs around the Globe}

\section{Facts and figures}

The 2016 survey of Global Entrepreneurship Monitor (Global Entrepreneurship Monitor, 2016) supports it too that female entrepreneurs everywhere launch their enterprise rather out of constraint than men. The number of female enterprises is the highest in those countries where the goal of enterprising activity is to generate the earnings necessary for survival. In some countries - Vietnam, the Philippines, Malaysia, Peru, Indonesia -, the proportion of female entrepreneurs is higher than the proportion of male ones, according to the data, they are typically young people. Senegal has the highest proportion of female entrepreneurs within the active female population in the 
world, $37 \%$ (40\% of men are entrepreneurs). The lowest figures of proportion come from Morocco, Italy, Bulgaria and Malaysia (hardly 3\%). In the latter two countries, the proportion of male entrepreneurs is low too, at the same time, in the former two countries, only the female willingness to launch an enterprise is low: the proportion of women does not reach half of the number of male entrepreneurs.

The gender differences manifesting themselves in the number of enterprises are the largest in the countries with medium earnings, however, in Latin American and the Caribbean, also in certain countries of Asia, the proportion of genders is approximately identical among the entrepreneurs, and the lowest proportions are typical of the MiddleEast and North-Africa. In these countries, the traditions and social norms do not support the independence of women, their taking up jobbed and especially their entrepreneurship.

In the former socialist countries, also owing to the collectivist economic past, this rate is relatively low, at the same time, e.g. in Russia -in the absence of other labour market alternatives -, the number of female entrepreneurs vigorously leapt forward. In countries with high earnings where reconciling work and family, and the opportunities of acquiring earnings in their own right are equally assured, the proportion of coerced female entrepreneurs is trifling. The lowest rate is typical of the Netherlands where parttime employment is outstandingly widespread (70\% among female employees) and moreover, part-time employment offers a decent livelihood, here the proportion of coerced female entrepreneurs is hardly $47 \%$ of the male coerced entrepreneurs. In general, public policies supporting the promotion of gender equality favour female employment, thus, for example, in Norway and Canada, there are less coerced female entrepreneurs than male ones. It refers to the different past of post-socialist countries, the different social participation of women, and the different traditions of entrepreneurial existence that, e.g., the proportion of coerced female entrepreneurs is also lower among Polish women who enjoy a higher appreciation than the Hungarian ones. For instance, in Croatia, due to self-employment, having subsisted in the Yugoslav economy and the major economic importance of tourism, female entrepreneurship has its traditions also, and in Romania, due to the regional differences, female enterprises have subsisted during the socialist era, too.

At the same time, the fact that there are less coerced female entrepreneurs than male ones can allude to the obligation of supporting women, stemming from the traditional gender roles. Hence, in Ireland, which nowadays can already be considered as a country with high earnings, yet is very conservative, the proportion of coerced female entrepreneurs is the lowest, however, the proportion of coerced female entrepreneurs inferior to the proportion of male ones, can be explained also with cultural reasons, female roles within the family, and the subordination of women, in Iran, India and Israel also. Whereas the lesser number of female entrepreneurs than male ones in China too is a consequence of entrepreneurial traditions deeply rooted in the culture.

According to the OECD statistics, from among the 34 member states (OECD, 2016), the willingness to assume risk is the highest among women in the SouthAmerican Brazil, Mexico and Chile, the Republic of South Africa, and this is the most important component of the entrepreneurial inclination. In these countries, just like in the United States, self-care has a great tradition, as opposed to the ,,providing states" where, on the one hand, as an inheritance from the post-socialist past, on the other hand, due to the extensive employment as workers, female entrepreneurial inclination is low. In these countries, the proportion of female entrepreneurs is 2.5 times lagging behind the 
proportion of male ones on average. They mostly operate their typically single-person enterprises in the service industry, in fields that require no high starting capital: in retail trade, consumer industry, at the same time, profitability is lower here, too. They hardly participate in manufacturing and the construction industry. In terms of their number, revenues, assets, profit - also of the performance indicators - survival rates, return, etc. they are lagging behind the men's enterprises.

\section{Female entrepreneurs in the developing and in the developed world}

Female entrepreneurs are typically highly qualified (Kevehazi, 2016) almost everywhere in the world, thus also in the developing countries. At the same time, stemming from their female identity, even in case of the most qualified ones, their knowledge is not identical to that of the men in order to allow them to launch and operate up-to-date and efficient enterprises, resulting in high profitability, since, for example, they have restricted access to IT technologic expertise, but also to the pieces of business information.

In societies with low level of education, uneducatedness can be attached to other, so-called intersectional disadvantages (belonging to a religious, ethnic minority, disability, etc.), which entirely exclude independent appearance for the affected women, in case of any field of their life. Being qualified, or belonging to the privileged social group however does not suffice by itself for the success of the enterprising activity, as it merely creates the demand for autonomy, eventually contributes to creating the selfconfidence necessary to the venture. At the same time, it does not guarantee either the possibility of independent decision-making or the financial background, or the supportive family or institutional environment hence it does not guarantee the increase in social/economic influence even in an otherwise entrepreneurship-friendly business environment.

In societies where patriarchal social norms are coupled with religious restrictions as well, merely the fact that somebody has been born a woman makes it impossible to become an entrepreneur. In the countries of the Middle-East and North-Africa, the prevailing of women's rights attached to personal freedom is not assured either, at the same time, in almost $2 / 3$ of the countries of the world, women's economic rights are infringed, and almost 44 countries restrict the duration of (paid) work-performance by women and 71 countries regulate legally the work-performance by women in certain sectors (World Bank, 2012). For example, it is natural in Asia that the husband disposes of the income earned by the woman. Although women living in the countries of Black Africa are restricted every day by the prejudices, the violence and discrimination directed at women, there is high proportion of them present in the craft industry, the light industry and the small-scale agriculture too. Having strengthened in the entrepreneurship, their influence has increased also, which is equally indicated by the exceptionally high proportion of female politicians.

\section{Female entrepreneurs in the developed world}

The state of gender equality is also formed by very diverse traditions and policies in the developed world. The progressive governments of societies having become prowomen due to historic reasons and/or as a result of the effort of feminist movements support with strategic and system-level public policies the women's economic independence, their labour-market participation and the compatibility of family and 
work. In these countries - as we have seen it previously, too -, female employment is high-level, and coerced female entrepreneurship is low-level.

For female entrepreneurs, flexibility, the compatibility of family and work constitute serious value. At the same time, like everywhere in the world, the pecuniary and emotional support of the family is a determinant factor in the developed world as well for women to operate as entrepreneurs. The husband's/partner's participation in raising the children and in the domestic tasks is cardinal from the aspect as to how free the female entrepreneur is from the aspect of time management, how exposed she is to stress while co-ordinating her manifold activities, and reconciling the external and internal expectations.

Women - intentionally or unintentionally - adopt various battling techniques in the course of harmonising their roles. The female role model widespread in the developed countries, the so-called superwoman strives to meet all expectations, yet, even with the involvement of a household employee, this often involves conflicts of value. Due to their female roles, however, they cannot entirely evolve in business life: on the one hand, they themselves restrict the expansion of their enterprises, on the other hand, due to their roles of private life, owing to their inflexibility in terms of time and geography, their participation is restricted in the business networks that continue to be characterised by male dominance. Owing to these factors - even if they themselves think differently -, in the environment's judgment, they strive less to have a successful enterprise, consequently, female enterprises are less attractive to investors, to creditors.

In countries where no political will exists to promote the equality of women's chances, female entrepreneurs endeavour to create a balance between their conflicts of roles by accepting the patriarchal conditions. Even if they recognize that these male prerogatives incommode them in deploying their skills, in order to comply with the masculine expectations of the entrepreneurial existence, they rather conceal, or precisely over-emphasize their femininity, and in the interest of success, they accept the men's rules of the game, they deny discrimination, and do not support either women who are less successful in their battling strategies or happen to attack the structural inequalities. It is part of the patriarchal bargain that female entrepreneurs are not independent even in this role of theirs, they are supported even as entrepreneurs: they are active in their husband's/partner's enterprise, or, besides the primary breadwinner - although they have an enterprise of their own -, they strive less to develop their enterprise, their efforts are rather aimed at acquiring earnings complementing the family income.

In case they are independent entrepreneurs, they do so far from the maledominated business environment, or, adjusting themselves to its disparagement, they perform their activity mostly in segregated, „feminine" business fields, with female clients, frequently under informal conditions. Although becoming an entrepreneur is assured to them, however, the entrepreneurship seldom assures them the possibility of acquiring significant earnings. The verbal- and physical harassment, violence ruling the business life dominated by men affects their business activity, too.

\section{Forms of inequalities}

To summarize: Among inequalities existing in the world of labour, the highestlevel inequalities can precisely be observed in the world of enterprises:

- There is lower proportion of female entrepreneurs (Vajda R. 2014). 
- The entrepreneurial activity of women is often of auxiliary nature, they often carry it out in their homes, often under informal conditions,

- Besides their mobility in terms of space, female entrepreneurs devote fewer working hours to the enterprise, reconciling work and family life means difficulty for them.

- Female enterprises mostly appear in feminine activities (horizontal segregation).

- Female enterprises are mostly single-person enterprises (vertical segregation).

- Female entrepreneurs are missing from the decision-making that serves the development of enterprises, from the representation of entrepreneurial interests; they do not participate in the business networks dominated by men.

- Women have lower earnings from entrepreneurial activity than the earnings of enterprises owned by men.

The capital supply of female enterprises is by far lower than the enterprises led by men, already from the start-up:

- they have more restricted share capital at their disposal, due to their earnings, inferior to those of men, they dispose of lower savings,

- they are less independent than men in decision-making on the use of family savings for an enterprise goal, also, within couples, men are less supportive in connection with the enterprising activity of women than the other way round,

- they involve investors to a lower proportion,

- their willingness to assume risks is lower, therefore they take up fewer borrowings to launch the enterprise.

The growth of female enterprises is of lower extent too than that of men-managed enterprises, due to similar reasons:

- they devote their accumulated earnings rather for goals related to family life,

- female entrepreneurs are less growth-oriented, since the primary goal of women - in the longer run by all means - is to create a balance between work and family,

- female entrepreneurs strive less to involve the contributors as they endeavour less to become executives to assume the additional burdens the employer tasks involve,

- very few of them take up borrowing, involve investors,

- the ability to reconcile enterprising activities with the female/family roles is an important criterion of success (Jaiswal et. al. 2011).

During their entrepreneurial activity, female entrepreneurs face numerous forms of discrimination. However, considering that women themselves also embrace the genderbased stereotypes, they are less sensitive to being directly or indirectly exposed to disadvantageous discrimination as women. In connection with this, legal awareness is of low level, it is hard for them to recognize the various forms of discrimination. Female entrepreneurs operating in a business environment dominated by men have related several situations which illustrate well the prejudices against women, the sexist belittling of women which can be described as general, the very widespread harassment, which, 
although those concerned perceive mostly as unpleasant due to their own stereotypical views, at the same time, they do not recognize at all whereby they have received unequal treatment, or have encountered adverse discrimination (Kevehazi, 2016).

\section{The importance of solving inequalities}

The role and influence of female entrepreneurship both increase in regions of the world with the most different economic opportunities and social traditions, a multitude of governments, international organisations, and prominent participants of the business world welcome the business networks of female entrepreneurs (McCracken et. al. 2015).

It is an increasingly acknowledged and recognized fact whereby enterprises led by women can, could substantially contribute to growth, the development of human environment, social mobility and integration, general welfare, therefore, the development of female enterprises is a highlighted priority for the most notable organisations, prominent in the field of developing international economy (EIGE, 2014). The international organisations particularly highlight in strategic documents in their communication whereby prevailing of the aspect of gender equality is of determinant importance for the sustainable economic and social development.

The action program formulated at the UNO World Conference in Beijing (1995) convened for ameliorating the position of women includes the objectives applicable to the prevailing of women's economic rights and independence; their equal access to resources, employment, markets and trade; the securing of their access to markets, pieces of information and technologies; the strengthening of their economic capacities and commercial networks as primary priorities. Since then these strategic goals have appeared, in addition to the economic development programmes of numerous organisations (e.g. ILO), in a great many governmental programs (e.g. USAID) too. Besides, a number of other transnational organisations, states and multinational companies also emphasize in their strategic documents and communication the importance of enforcing the aspect of gender equality, hence the aspect of women's and girl babies' security appears in the UN endeavours aimed at maintaining peace. Despite the unequivocal positions taken, for the time being, the majority of states, international institutions still apply mostly obsolete models, public policies.

Whilst it is general knowledge that macroeconomic- and social-economic environment are determinant from the aspect of entrepreneurial success, decision-makers and reasoners usually disregard the gender, social affiliation, family and other circumstances of the enterprises, not applying the gender-based approach that takes intersectionality also into consideration when describing the position of enterprises and formulating their ideas aimed at their development. Application of the gender-sensitive approaches creates the genuine opportunity to increase the role of female entrepreneurs, understand their disadvantages and eliminate impediments. A part of these builds on the differences between women and men, others on the similarities - yet, these differences of opinion have no significance from the aspect of elaborating the solutions, since in fact, it is patriarchal society itself whose structures and mentality hinders women in access to the resources, segregates and discriminates them.

\section{A proposed model for solving inequalities}

The gender-sensitive approach in public policies - gender mainstreaming - creates the genuine opportunity to increase the role of female entrepreneurs, understand their 
disadvantages and eliminate the barriers in front of them. This requires simultaneous interventions

- consistent manifestations in order to proclaim the values to eliminate the prejudices, shaping the approach positively;

- by means of deeds, actions - e.g. prizes, competitions, sponsorship programs -, with systematic initiatives aimed at women;

- moreover, in certain countries, also at a strategic level, female executives and female enterprises are equally supported by programmes of macroeconomy and public policy.

Genuine changes are achievable in the field of eliminating the social and economic inequalities between the genders if every concerned participant simultaneously appears at all three levels. As I am convinced whereby welfare and security interpreted at the individual and broader levels can be realised exclusively by integrating the objective of gender equality, by re-thinking the patriarchal values, strengthening the women, promoting their economic independence and extending their undertaking of social role.

With I wish to provide assistance is the following model (depicted by Table 1) for the forthcoming years to plan the action and follow it up.

\begin{tabular}{|l|l|l|l|}
\hline $\begin{array}{c}\text { What is/can (could) be done for } \\
\text { gender equality }\end{array}$ & $\begin{array}{c}\text { by the state } \\
\text { (macro-level) }\end{array}$ & $\begin{array}{c}\text { by the world of } \\
\text { labour } \\
\text { (micro-level) }\end{array}$ & $\begin{array}{c}\text { by the individual } \\
\text { (man and woman) }\end{array}$ \\
\hline $\begin{array}{l}\text { in the field of rethinking the } \\
\text { values, eliminating the prejudices, } \\
\text { stereotypes }\end{array}$ & & & \\
\hline $\begin{array}{l}\text { at the level of deeds, actions, } \\
\text { practices }\end{array}$ & & & \\
\hline $\begin{array}{l}\text { in the scope of influencing public } \\
\text { policies and strategies }\end{array}$ & & & \\
\hline
\end{tabular}

Table 1 Model of solving gender inequalities

\section{Conclusions}

I think that the elimination of hierarchical gender relations would result in essential changes with regard to determining the priorities of society, creating an opportunity for global processes of the world to take a different direction. However, the increasing economic power of women is indispensable to create and maintain genuine influence, change the patriarchal set of values which rushes the world into danger. Detailed elaboration of the above-presented model would mean a systematic action plan aimed to put an end to the economic- and power inequalities between the genders, and my subsequent researches will focus on that.

\section{References}

Acsády, J., Biegelbauer, A., Paksi, V., Somogyi, B., Szalma, I. 2012. Traditional and alternative patterns in the social construction of care in Gendering Post-socialist Transition: Studies of Changing Gender Perspectives (edited by Daskalova, K., Horstein Tomic, C., Kaser, K., Radunovic). F. ERSTE Foundation Series.

Bernhardt, E.M. 2000. Female Careers between Employment and Children. European Observatory on Family Matters in Sevilla. September 15-16, page 10. 
Braidotti, R., Charkiewicz, E., Hausler, S., Wieringa, S., 1994. Women, the Environment and Sustainable Development: Towards a Theoretical Synthesis, Zed books.

Castiello, J. K., Misra, J., McCurley, K. 2013. Intersectionality in Sociology in http://www.socwomen.org/

Eagly, A. H., Carli, L. L. 2007. Through the labyrinth: The truth about how women become leaders. Cambridge. MA: Harvard Business School Press.

EIGE. 2014. European Institute for Gender Equality. 2014. Gender equality and economic independence: part-time work and self-employment, Review of the Implementation of the Beijing Platform for Action in the EU Member States Report of the European Institute for Gender Equality (EIGE)

European Union Agency for Fundamental Rights. 2014. Violence against women: an EU-wide survey. Main results report.

Ferguson, A. Hennessy, R., Nagel, M. 2016. Feminist Perspectives on Class and Work. The Stanford Encyclopaedia of Philosophy (Winter Edition), Edward N. Zalta (ed.), forthcoming URL $=<$ https://plato.stanford.edu/archives/win2016/entries/feminismclass $/>$.

Fitzpatrick, B., 2016. Tactical rape in war and conflict: International recognition and response, Policy Press.

Frost, S. 2017. The 2017 Global Information Security Workforce Study: Women in Cibersecurity, Center for cybersecurity and education.

GENDERNET. 2012. The OECD DAC Network on Gender Equality: Women's economic empowerment, Poverty Reduction and Pro-Poor Growth: The Role of Empowerment. OECD

Global Entrepreneurship Monitor. 2016. Published online: http://gemconsortium.org/report

Haq, K. 1999. "Women in security" in Toda Institute for Global Peace and Policy Research: Worlds Apart: Human Security and Global Governance, Chapter 5. I.B.Tauris.

Hudson, V.M., Caprioli, M., Ballif-Spanvill, B., McDermott, R., Emmett, C.R. 2009. The Heart of the Matter: The Security of Women and the Security of States

Jaiswal, R., Baruah, M., Golaghat, 2011. A. Development of Women Entrepreneurship for Inclusive Growth. Golaghat Commerce College, page 4.

Kandiyoti, D. 1988. Bargaining with Patriarchy. 2. Sage Publications, Inc. pp. 274-290. ISSN 0891-2432

Kelley, D., Singer, S., Herrington, M. 2015. Global entrepreneurship monitor. http://gemconsortium.org/report/4948

Kevehazi K. 2016. A nő, ha vállalkozik, Published online: http://jollet.com/projektek/aktualis-projektek/nora-vallalkozik/

Kevehazi, K. 2016. Lekicsinylésre nem adunk. http://jol-let.com/projektek/aktualisprojektek/nora-vallalkozik/

Kevehazi, K. 2016. Nemzetközi trendek, tapasztalatok a női vállalkozások fejlesztésében., Published online: http://jol-let.com/magyar/wpcontent/uploads/Nemzetk\%C3\%B6zi-gyakorlatok-vegleges.pdf 
Kirkwood, J.J. 2009. Motivational Factors in a Push-Pull Theory of Entrepreneurship. Gender in Management, July 24 (5):346-364

Manjoo, R., McRaith, C. 2010. Gender-Based Violence and Justice in Conflict and Post-Conflict Areas. Cornell International Law Journal.

McCracken, K., Marquez, S., Kwong, C., Stephan, U., Castagnoli, A., Dlouhá, M. 2015. Women entrepreneurship, closing the gap in access to financial and other services in social entrepreneurship. European Parliament, CEuropean Union, Brussels.

Minniti, M. 2010. Female Entrepreneurship and Economic Activity. European Journal of Development Research 2010, Vol.22, p. 294-312.

OECD. 2016. Entrepreneurship at a Glance. Published online, http://www.oecd.org/std/business-stats/entrepreneurship-at-a-glance-22266941.htm

Pérez-Quintana A., Hormiga, E. 2015. The role of androgynous gender stereotypes in entrepreneurship, UB Business Working Papers 2015/2

PWC. 2012. Empowering the Third Billion, Women and the world of work. Strategy\& Formerly Booz and company.

Tickner J.A. 2004. What is Your Research Program? Some Feminist Answers to IR's Methodological Questions, Working Paper No. 203, CConsortium on Gender, Security, and Human Rights

UN Report World's Women 2015. Violence against women, Chapter 6

Vajda, R. 2014. Munkaerőpiac, foglalkoztatás, vállalkozónők, A nők teljes értékü munkavállalásának akadályairól és esélyeiről. Nőtlen évek ára, A nők helyzetének közpolitikai elemzése 1989-2013 (ed.: Juhász Borbála), Budapest, Magyar Női Érdekérvényesítő Szövetség, p. 111.

Waring, M. 1989. Counting for Nothing: If Women Counted: A New Feminist Economics. London: Macmillan London.

World Bank. 2012. Women Business and the Law. Removing barriers to economic inclusion. Published online, http://wbl.worldbank.org 